\title{
PENYULUHAN KESIGAPAN IBU RUMAH TANGGA DI BANTARAN SUNGAI LULUT DALAM MITIGASI BENCANA BANJIR
}

\author{
Siti Kaidah ${ }^{1}$, Husnul Khatimah ${ }^{1}$, Lia Yulia Budiarti ${ }^{2}$ \\ ${ }^{1}$ Departemen Biomedik, Fakultas Kedokteran Universitas Lambung Mangkurat \\ ${ }^{2}$ Departemen Mikrobiologi Parasitologi, Fakultas, Kedokteran Universitas Lambung Mangkurat \\ sikadatun1@gmail.com, khatynunul@gmail.com, 1ybudiarti@ulm.ac.id
}

\begin{abstract}
Abstrak
Wilayah bantaran Sungai Lulut Kota Banjarmasin berada pada ketinggian di bawah permukaan laut dengan kondisi daerah berpaya-paya dan digenangi air sungai. Keadaan tersebut menjadikan wilayah ini rentan mendapat bencana banjir. Bencana banjir bandang yang terjadi pada Januari 2021 menyebabkan sebagian besar warga masyarakat Sungai Lulut terdampak dan mengungsi. Diperlukan pengetahuan tentang kesiapsiagaan dan upaya-upaya mengurangi risiko bencana banjir pada anggota masyarakat di wilayah berpotensi banjir. Tujuan PKM ini adalah memberikan penyuluhan kepada ibu rumah tangga tentang kesigapan dan upaya yang dapat dilakukan dalam mitigasi bencana banjir. Mitra sasaran kegiatan PKM ini adalah ibu-ibu rumah tangga yang bertempat tingal di Kelurahan Sungai Lulut. Hasil jawaban kuisioner dari ibu-ibu rumah tangga, didapatkan ada perbedaan tingkat pengetahuan sebelum dan sesudah penyuluhan. Setelah mendapat penyuluhan, lebih dari $80 \%$ ibu-ibu rumah tangga paham tentang kesigapan dan upaya yang dapat dilakukannya bersama keluarga sebelum, saat dan setelah bencana banjir. Kesimpulan terdapat peningkatan pengetahuan kesigapan ibu rumah tangga di bantaran sungai lulut dalam mitigasi bencana banjir. Diharapkan pengetahuan yang didapat setelah penyuluhan dapat diterapkan oleh mitra sasaran dan dapat diinformasikannya pada masyarakat lainnya di lingkungan rawan banjir.
\end{abstract}

Kata Kunci : bantaran sungai, ibu rumag tangga, kesigapan, mitigasi banjir

\section{PENDAHULUAN}

Bencana banjir merupakan fenomena alam yang umumnya terjadi pada musim penghujan. Setiap sungai berpotensi banjir. banjir merupakan peristiwa atau rangkaian peristiwa yang mengancam dan mengganggu kehidupan dan penghidupan masyarakat sehingga mengakibatkan timbulnya korban jiwa manusia, kerusakan lingkungan, kerugian harta benda, dan dampak psikologis (Bakornas PB, 2007). Menurut UU no 24 Tahun 2007 tentang Penganggulangan Bencana, bencana merupakan peristiwa atau rangkaian peristiwa yang mengancam dan mengganggu kehidupan dan penghidupan masyarakat yang disebabkan oleh faktor alam dan atau faktor non alam maupun faktor manusia sehingga mengakibatkan timbulnya korban jiwa 
manusia, kerusakan lingkungan, kerugian harta benda, dan dampak psikologis. Sedangkan menurut Muhammadiyah Disaster Management Center (MDMC), bencana merupakan gangguan serius yang meluas dan bisa melumpuhkan fungsifungsi masyarakat, serta mengakibatkan kerugian material ataupun immaterial

Banjir di wilayah kota Banjarmasin, yang merupakan kota seribu sungai, hampir setiap tahun terjadi. Bencana banjir yang terjadi pada Januari 2021 memberikan dampak besar bagi masayarakat di Kota Banjarmasin, diantaranya di wilayah Sungai Lulut. Terdapat sekitar $1.585 \mathrm{KK}$ atau 3.701 jiwa pengungsi yang sebagian besar merupakan warga Sungai Lulut (BPBD Kota Banjarmasin, 2021). Wilayah Sungai Lulut yang merupakan bagian wilayah Kecamatan Banjarmasin Timur, sebagian besar wilayah ini digenangi air yang dialiri oleh Sungai Martapura dan bermuara di Sungai Barito. Wilayah Sungai Lulut memiliki luas wilayah sekitar $8,63 \mathrm{Km}^{2}$ dan secara topografis wilayah ini terletak pada ketinggian tempat rata-rata $0.16 \mathrm{~m}$ dibawah permukaan laut (dpl) dengan kondisi daerah berpaya-paya dengan banyak anak sungai, sehingga pada waktu pasang, hampir seluruh wilayah digenangi air sungai yang meluap. Kondisi ini menjadikan wilayah ini setiap tahun mengalami banjir (Kelurahan Sungai Lulut, 2020). Bencana banjir bandang pada Januari 2021 yang terjadi di Kota Banjarmasin, tidak hanya diakibatkan akibat luapan air sungai yang di akibatkan oleh hujan deras dan kiriman air dari lintasan air dari wilayah hulu sungai. (BPBD Kota Banjarmasin, 2021).

Hasil analisis situasi lingkungan pada masyarakat di bantaran Sungai Lulut Banjarmasin yang dilakukan satu bulan setelah bencana banjir, masih didapatkan perumahan dan lingkungan masyarakat yang berada disekitar bantaran sungai yang kotor dan kurang higienis, dengan tumpukan sampah yang terbawa luapan air sungai dan aliran air hujan yang menutupi lingkungan perumahan, selokan, serta bahu jalan-jalan umum. Menurut informasi masyarakat setempat, sudah biasa perumahan masyarakat tergenang bila sedang musim hujan, tetapi banjir tahun 2021 merupakan bencana banjir bandang dengan dampak yang paling besar. Banyak masyarakat merasa kurang sigap dalam menghadapi bencana banjir, sehingga berdampak pada kerugian material maupun nonmaterial. Curah hujan yang tinggi disertai luapan air sungai dan air dengan ketinggian air mencapai lebih dari tiga meter, menyebabkan banyaknya akses jalan yang terputus. Akibatnya, menjadikan kendala bantuan bagi pengungsi dalam hal suplai pangan/makanan dan obatobatan, serta air bersih baik untuk dikonsumsi maupun untuk membersihkan diri. Setelah bencana banjir masyarakat masih perlu waktu cukup banyak, selain untuk pemulihan kesehatan, juga untuk bebenah di lingkungan rumahnya, maupun di lingkungan sekitar bantaran sungai.

Bencana banjir senantiasa memiliki potensi untuk kembali terjadi, sehingga sangat penting dilakukannya mitigasi bencana banjir, untuk mengantisipasi dampak dari bencana tersebut. Pengetahuan dan pemahaman masyarakat yang masih rendah dalam menghadapi bencana dapat diminimalisir dengan melakukan sosialisasi tentang kesiapan masyarakat dalam menghadapinya. Sosialisasi mitigasi bencana ini perlu dilakukan agar masyarakat tanggap, tangkas dan cepat sehingga dapat menghindari jatuhnya korban bencana (Nefilinda, dkk., 2019).

Mitigasi dilakukan untuk mengurangi risiko bencana bagi masyarakat yang berada pada Kawasan rawan bencana (Hermon, 2012; Lindarto et al., 2018; Shalihati et al., 2016). Upaya yang harus dilakukan adalah dengan cara memberikan sosialisasi lebih intens khususnya kepada masyarakat yang tinggal di wilayah rawan banjir seperti halnya pada masyarakat di Sungai Lulut Banjarmasin. Menurut UU No. 24 Tahun 2007, kegiatan mitigasi dapat dilakukan melalui penyelenggaraan pendidikan, penyuluhan dan pelatihan baik secara konvensional maupun modern (Hermon, 2012). Penyuluhan dan pendidikan tentang kesehatan diri dan lingkungan kepada masyarakat di wilayah banjir dapat dilakukan melalui berbagai media, tujuannya untuk meningkatkan pemahaman, kepedulian dan peran masyarakat (Lindarto et al., 2018; Shalihati et al., 2016). 
Berlandaskan analisis situasi dan permasalahan yang di hadapi masyarakat di Kelurahan Sungai Lulut Kota Banjarmasin, maka diperlukan suatu kegiatan pengabdian kepada masyarakat (PKM) tentang pentingnya kesigapan dari masyarakat yang ada di bantaran sungai dan rawan banjir sebagai upaya mitigasi banjir. Kesiapsiagaan adalah serangkaian kegiatan yang dilakukan untuk mengantisipasi bencana melalui pengorganisasian serta melalui langkah yang tepat guna dan berdaya guna (UU RI No.24 Tahun 2007). Kesiapsiagaan merupakan tindakantindakan yang memungkinkan pemerintahan, organisasi, masyarakat, komunitas, dan individu untuk mampu menanggapi suatu situasi bencana secara cepat dan tepat guna.

Tujuan dari kegiatan penyuluhan ini adalah untuk memberikan penyuluhan tentang kesigapan masyarakat di bantaran Sungai Lulut dalam mitigasi bencana banjir. Target sasaran pada kegiatan penyuluhan ini adalah ibu-ibu rumah tangga, mengingat ibu rumah tangga memiliki banyak waktu berada di dalam rumah, serta aktivitas ibu rumah tangga dalam kegiatan pengajian rutin/yasinan di mushola lingkungan perumahannya, diharapkan memudahkan terinformasikannya materi penyuluhan kepada seluruh anggota keluarga. Target capaian dari hasil kegiatan ini adalah $80 \%$ mitra sasaran, memahami materi penyuluhan yang disampaikan. Diharapkan masyarakat yang bertempat tinggal di bantaran sungai dan rawan banjir dapat berperilaku sigap saat musim hujan sebagai upaya mitigasi bencana banjir. Kesigapan masyarakat tidak saja saat terjadi banjir, tetapi juga sebelum banjir tiba dan setelah banjir reda.

\section{METODE}

Kegiatan penyuluhan ini dilaksankan secara pertemuan langsung/luring bersamaan dengan jadwal kegiatan yasinan rutin ibu-ibu rumah tangga di kelurahan Sungai Lulut Banjarmasin. Tahapan pelaksanaan penyuluhan dimulai dengan identifikasi melalui survei pendahuluan untuk menganalisis situasi permasalahan yang ada pada masyarakat di bantaran sungai dengan topografi rawan banjir. Identifikasi ini diperlukan untuk menentukan langkah tepat dalam kesiapsiagaan banjir yang perlu dilakukan. Tahapan selanjutnya adalah (1) pertemuan awal dengan pihak RT dan kelurahan untuk menentukan tempat dan target sasaran, (2) Sosialisasi rencana dan tujuan dari kegiatan, dan (3) kesepakatan waktu pelaksanaan dengan beberapa target sasaran.

Tim pelaksana juga melaksankan koordinasi internal persiapan sarana dan prasarana yang akan digunakan dalam pelaksanaan PKM ini. Tahapan dari tim pelaksana penyuluhan diantaranya adalah menentapkan time frame kegiatan, menetapkan desain pengabdian, membuat instrumen, dan draf materi kegiatan penyuluhan (file ppt, leaflet, banner dan standard operational procedure (SOP) tentang kesiapsiagaan bencana banjir). Selanjutnya menetapkan tahapan jadwal kegiatan penyuluhan, merencanakan dan mempersiapkan alat peraga pada saat pelaksanaan penyuluhan.

Sasaran/peserta kegiatan terpilih adalah ibu-ibu rumah tangga di lingkungan Kelurahan Sungai Lulut Banjarmasin. Semua peserta kegiatan merupakan anggota masyarakat yang terdampak bencana banjir bandang yang terjadi pada Januari 2021. Kegiatan ini dilaksanakan secara tatap muka langsung /luring pada 18-19 Juni 2021, bertempat di Langgar Ar Rahman Kelurahan Sungai Lulut. Jumlah peserta yang hadir mengukuti keagitan penyuluhan ini adalah sebanyak 30 orang peserta. Kegiatan penyuluhan ini dilaksanakan masih pada pandemi Covid-19, sehingga pelaksanannya disesuaikan dengan prosedur kesehatan (prokes).

Penyuluhan dilakukan dengan metode ceramah dan tanya jawab. Materi penyuluhan pada kegiatan penyuluhan ini disampaikan secara sederhana, informatif dan menarik dengan menggunakan media-media ppt, leafleat, dan poster. Materi yang disampaikan diataranya: (1) penyebab banjir, (2) dampak banjir, (3) dan peran masyarakat dalam mitigasi banjir. Bahasan materi berkaitan kesiapsiagaan banjir dalam mitigasi banjir meliputi (1) tindakan sebelum terjadi banjir, (2) Tindakan saat terjadi banjir, dan (3) tindakan setelah banjir. 
Evaluasi keberhasilan terhadap penyuluhan yang dilakukan diperoleh berdasarkan hasil jawaban kuisioner dari mitra sasaran. Kuisioner berupa soal pretest dan posttest yang berkaitan dengan materi kesigapan keluarga dan masyarakat di bantaran sungai dalam upaya mitigasi bencana banjir.

\section{HASIL DAN PEMBAHASAN}

Penyuluhan mengenai beberapa tindakan kesigapan yang dapat dilakukan oleh masyarakat di bantaran sungai sebagai upaya mitigasi banjir telah dilaksankan dan disampaikan secara sederhana ditunjang dengan video/poster contoh-contoh tindakan yang dapat dilaksankan di tataran rumah tangga dan masyarakat bantaran sungai, yang rawan terhadap bencana banjir. Paparan penyuluhan diawali dengan materi mengenai penyebab banjir dan dampaknya bagi masyarakat terutama pada masyarakat yang bertempat tinggal di bantaran sungai. Selanjutnya penjelasan mengenai materi peran masyarakat dalam mitigasi banjir; pada materi ini membahas upaya atau tindakan dalam keluarga dan masyarakat dalam menagani masalah banjir. Terdapat tiga aspek tindakan kesiagaan yang dapat dilakukan oleh keluarga atau masyarakat diantaranya yaitu: kesiagaan dalam menghadapi banjir, tindakan saat terjadi banjir, serta tindakan pasca bencana banjir. Berikut gambar saat kegiatan penyuluhan.

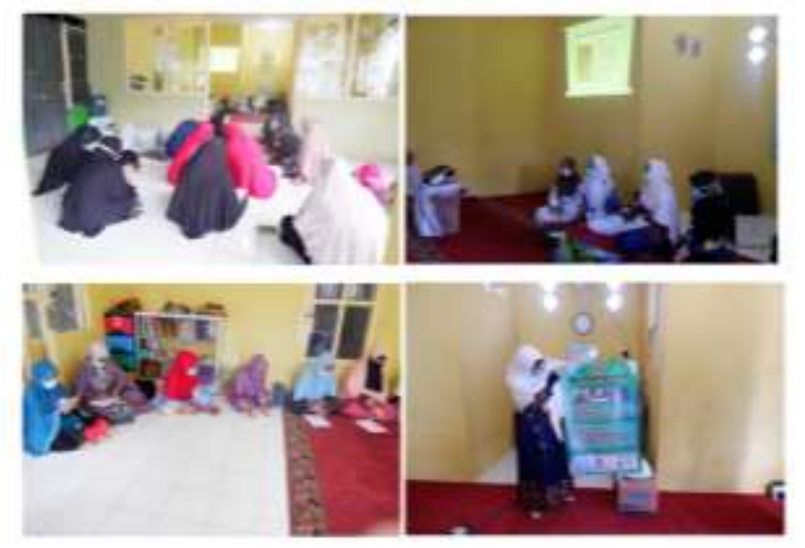

Gambar 1. Suasana kegiatan penyuluhan

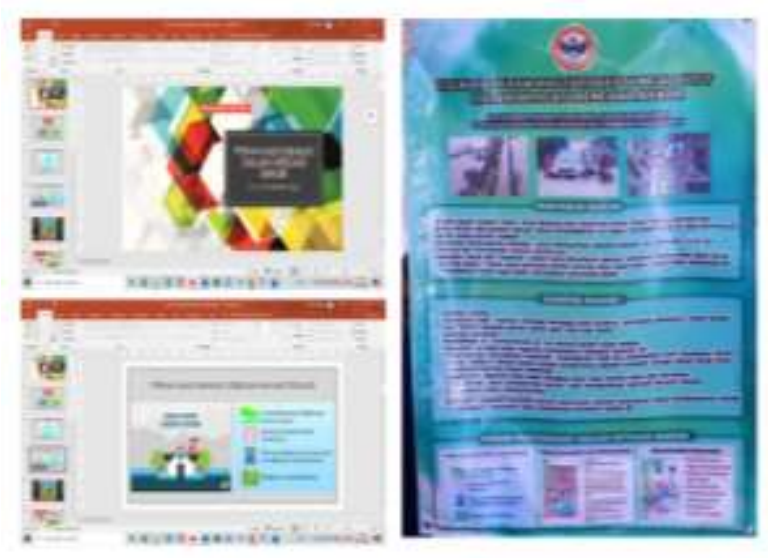

Gambar 2. Peraga (PPT) dan poster penyuluhan

Gambar 1 memperlihatkan suasana saat kegitan penyuluhan. Secara umum paserta kegiatan memiliki pengetahuan mengenai penyebab dan dampak dari bencana banjir. Namun, pengetahuan tersebut perlu diimplementasikan dalam kehidupan masyarakat, terutama pada masyarakat di wilayah bantaran sungai dan rawan banjir. Gambar 2 . memperlihatkan power point presentation dan poster yang dipergunakan sebagai alat bantu penyampaian materi penyuluhan.

Banjir adalah suatu kondisi fenomena bencana alam yang memiliki hubungan dengan jumlah kerusakan dari sisi kehidupan dan material. Banjir yang terjadi hampir setiap tahun di Indonesia menyebabkan kerugian yang sangat besar, baik berupa korban jiwa maupun materil, sehingga mitigasi bencana banjir sangat diperlukan untuk dilaksanakan. Banjir merupakan bencana alam yang ke tiga terbesar di dunia yang telah banyak menelan korban jiwa dan kerugian harta benda (Aryono, 2011). Banjir adalah peristiwa terbenamnya daratan yang biasanya kering, oleh air yang berasal dari sumbersumber air yang ada disekitar daratan tersebut seperti sungai, danau maupun laut, yang mana genangan air tersebut tidak permanen. Jadi banjir terjadi disebabkan oleh air yang ada di dalam sumber air naik permukaannya atau meningkat volumenya sehingga meluap menggenangi daratan disekitarnya (Tim Panca Aksara, 2017)

Secara umum, ada beberapa faktor yang menyebabkan terjadinya banjir. Faktor-faktor 
tersebut antara lain: 1). kondisi alam seperti letak geografis wilayah, kondisi toporafi, dan geometri sungai; peristiwa alam seperti curah hujan dan lamanya durasi hujan, pasang surut air laut, erosi dan sedimentasi, dan aliran lahar dingin; dan 2). aktifitas manusia seperti pembudidayaan daerah dataran banjir, pemanfaatan tata ruang di dataran banjir yang tidak sesuai, belum adanya pola pengelolaan dan pengembangan dataran banjir, pemukiman di bantaran sungai, sistem drainase yang tidak memadai, terbatasnya tindakan mitigasi banjir, kurangnya kesadaran masyarakat di sepanjang alur sungai, penggundulan hutan di daerah hulu, hingga terbatasnya upaya pemeliharaan bangunan pengendali banjir.

Sebagai fenomena alam yang terkait dengan ulah manusia, banjir terjadi akibat akumulasi beberapa faktor yaitu: hujan, kondisi sungai, kondisi daerah hulu, kondisi daerah budidaya dan pasang surut air laut. Potensi terjadinya ancaman bencana banjir saat ini disebabkan keadaan badan sungai rusak, kerusakan daerah tangkapan air, pelanggaran tata-ruang wilayah, pelanggaran hukum meningkat, perencanaan pembangunan kurang terpadu, dan disiplin masyarakat yang rendah (BNPB, 2011).

Salah satu dampak bencana terhadap menurunnya kualitas hidup penduduk dapat dilihat dari berhagai permasalahan kesehatan masyarakat yang terjadi. Bencana yang diikuti dengan pengungsian berpotensi menimhulkan masalah kesehatan yang sebenamya diawali oleh masalah bidang/sektor lain. Bencana gempa bumi, banjir, longsor dan letusan gunung berapi, dalam jangka pendek dapat berdampak pada korban meninggal, korban cedera berat yang memerlukan perawatan intensif, peningkatan risiko penyakit menular, kerusakan fasilitas kesehatan dan sistem penyediaan air. Timbulnya masalah kesehatan antara lain berawal dari kurangnya air hersih yang berakihat pada buruknya kebersihan diri, buruknya sanitasi lingkungan yang merupakan awal dari perkembangbiakan beberapa jenis penyakit menular. Persediaan pangan yang tidak mencukupi juga merupakan awal dari proses terjadinya penurunan derajat kesehatan yang dalam jangka panjang akan mempengaruhi secara langsung tingkat pemenuhan kebhutuhan gizi korhan bencana (Widayatun \& Fatoni, 2013).

Peristiwa bencana yang ditimbulkan oleh gejala alam maupun yang diakibatkan oleh kegiatan manusia, baru dapat disebut bencana ketika masyarakat atau manusia yang terkena dampak oleh peristiwa itu tidak mampu untuk menanggulanginya (Nurjanah et al. 2011). Manajemen bencana adalah hal yang sangat diperlukan sebagai tindakan dalam penanggulangan bencana untuk mengurangi bahkan mencegah dampak bencana yang mungkin terjadi mengingat saat ini semakin banyak bencana alam yang terjadi. Manajemen bencana pada dasarnya berupaya untuk menghindarkan masyarakat dari bencana, baik dengan mengurangi kemungkinan munculnya hazard maupun mengatasi kerentanan. Konsep pengelolaan bencana telah mengalami pergeseran paradigma dari pendekatan konvensional menuju pendekatan holistik (menyeluruh).

Orientasi dari pandangan konvensional adalah pada pemenuhan kebutuhan darurat berupa pangan, penampungan darurat, kesehatan, dan penanganan krisis. Tujuannya adalah menekan kerugian, kerusakan dan secepatnya memulihkan keadaan pada kondisi semula. Pandangan yang berkembang selanjutnya menuju pendekatan holistik (menyeluruh), yaitu paradigma mitigasi, yang tujuannya lebih diarahkan pada identifikasi daerah daerah yang rawan bencana, mengenali polapola yang dapat menimbulkan kerawanan, serta melakukan tindakan tindakan mitigasi, baik yang bersifat struktural maupun non-struktural. (Nurjanah et al. 2011). Mitigasi secara nostuktural dapat dilakukan melalui penyelenggaraan pendidikan, penyuluhan dan pelatihan baik secara konvensional maupun modern. (Hermon, 2012; Shalihati et al., 2016; Lindarto et al., 2018;).

Tujuan pengelolaan bencana dalam paradigma pengurangan risiko bencana adalah meningkatkan kemampuan masyarakat untuk mengelola dan menekan risiko terjadinya bencana. Pendekatan ini memandang masyarakat sebagai subjek dan bukan objek dari pengelolaan bencana 
dan proses pembangunan. Manajemen bencana merupakan ilmu pengetahuan yang terkait dengan upaya untuk mengurangi risiko, yang meliputi tindakan persiapan sebelum bencana terjadi, dukungan, dan membangun kembali masyarakat saat bencana terjadi. Secara umum, pengeloaan bencana merupakan proses terus menerus yang dilakukan oleh individu, kelompok, dan komunitas dalam mengelola bahaya sebagai upaya untuk menghindari atau mengurangi dampak akibat bencana. (Nurjanah et al. 2011)

Berdasarkan hasil jawaban kuisioner dari peserta kegiatan penyuluhan ini, didapatkan pengetahuan masyarakat tentang peran masyarakat dalam upaya mitigasi banjir masih kurang. Berikut tabel hasil pretest dan postest dari peserta kegiatan PKM ini.

Tabel 1. Hasil Pretest dan posttest pengetahuan sasaran tentang kesiagaan dalam menghadapi banjir

\begin{tabular}{ccccc}
\hline Pengetahuan & \multicolumn{2}{c}{ Pretest } & \multicolumn{2}{c}{ Posttest } \\
\cline { 2 - 5 } & $\begin{array}{c}\text { Jumlah } \\
\text { peserta }\end{array}$ & $\%$ & $\begin{array}{l}\text { Jumlah } \\
\text { peserta }\end{array}$ & $\%$ \\
\hline Baik & 0 & 0 & 30 & 100 \\
\hline Cukup & 1 & 3,3 & 0 & 0 \\
\hline Kurang & 29 & 96,7 & 0 & 0 \\
\hline Jumlah & 30 & 100 & 30 & 100 \\
\hline
\end{tabular}

Tabel 2. Hasil Pretest dan posttest pengetahuan sasaran tentang Tindakan saat terjadi banjir dan pasca banjir

\begin{tabular}{|c|c|c|c|c|}
\hline \multirow[t]{2}{*}{ Pengetahuan } & \multicolumn{2}{|c|}{ Pretest } & \multicolumn{2}{|c|}{ Posttest } \\
\hline & $\begin{array}{l}\text { Jumlah } \\
\text { peserta }\end{array}$ & $\%$ & $\begin{array}{l}\text { Jumlah } \\
\text { peserta }\end{array}$ & $\%$ \\
\hline Baik & 0 & 0 & 30 & 100 \\
\hline Cukup & 2 & 6,7 & 0 & 0 \\
\hline Kurang & 28 & 93,3 & 0 & 0 \\
\hline Jumlah & 30 & 100 & 30 & 100 \\
\hline
\end{tabular}

Tabel 1 dan 2, menjelaskan bahwa setelah dilakukan kegiatan penyuluhan, didapatkan peningkatan pengetahuan dan pemahaman kesiagaan masyarakat dalam menghadapi bencana banjir dan sebagai upaya mitigasi bencana banjir. Kegiatan penyuluhan dapat dikatakan berhasil melebihi target capaian yaitu $80 \%$ peserta memahami isi materi penyuluhan ini. Materi kegiatan pada penyuluhan merupakan hal yang baru didapat oleh masyarakat di bantaran Sungai Lulut ini mengingat penyampaian materi dilaksanakan setelah terjadinya bencana banjir bandang pada Januari 2021, yang banyak menimbulkan dampak luas bagi masyarakat, khususnya bagi masyarakat di bantaran sungai.

Menurut UndangUndang RI Nomor 24 Tahun 2007, kesiapsiagaan merupakan serangkaian kegiatan yang dilakukan untuk mengantisipasi bencana melalui pengorganisasian serta melalui langkah yang tepat guna dan berdaya guna. Kesiapsiagaan juga merupakan suatu proses yang saling berkesinambungan dan terarah yang dihasilkan untuk mengurangi risiko terjadinya korban jiwa. Kesiapsiagaan lebih ditujukan untuk menghadapi kondisi sesaat setelah bencana dan upaya pemulihan kembali ke kondisi normal. Upaya-upaya yang dapat dilakukan pada tahap kesiapsiagaan ini diantaranya mempersiapkan diri untuk melakukan pertolongan pertama setelah terjadi bencana, bagaimana melakukan koordinasi dalam kondisi tanggap darurat, serta bagaimana melakukan evakuasi dari daerah yang terkena bencana ke daerah yang aman (International of Red Cross and Red Cresscent Society, 2016)

Rencana Kesiapsiagaan Mitigasi Bencana Banjir dan pendidikan kesiapsiagaan bencana banjir merupakan salah satu langkah penting sebagai upaya mengurangi dampak bencana. Secara ilmiah mitigasi (mitigate) berarti tindakan untuk mengurangi bahaya supaya kerugian dapat diperkecil. Mitigasi meliputi tindakan perlindungan yang dapat diawali dari persiapan sebelum bencana itu berlangsung, menilai bahaya bencana, penanggulangan bencana, berupa penyelamatan, rehabilitasi dan relokasi. Dari sekian banyak kegiatan mitigasi, satu yang paling 
strategis adalah pembelajaran atau pendidikan. Pendidikan merupakan wahana yang efektif untuk membangun perilaku dalam menghadapi bencana (Ahmad, 2013)

Menurut BNPB (2017), ada tiga faktor utama untuk menyusun rencana kesiapsiagaan menghadapi bencana yaitu: 1) Memiliki sebuah rencana darurat keluarga yang meliputi: analisis ancaman sekitar, identifikasi titik kumpul, nomor kontak penting, mengetahui jalur evakuasi, identifikasi lokasi untuk mematikan air, gas dan listrik, identifikasi titik aman didalam bangunan atau rumah, identifikasi anggota yang rentan (anak-anak, lanjut usia, ibu hamil dan penyandang disabilitas). 2) Menyimpan 10 benda yang dibutuhkan saat bencana yaitu, air minum untuk 310 hari, makanan untuk 3- 10 hari, obat P3K, obat-obatan pribadi, lampu senter (dan ekstra baterai), sejumlah uang dan dokumen penting (akta kelahiran, sertifikat tanah atau rumah, ijazah, dokumen asuransi, dan surat kepemilikan asset), pakaian, jaket, sepatu, peralatan (peluit, sarung tangan, pisau serbaguna, masker dan pelindung kepala), dan pembersih higienis (tisu basah, hand sanitizer, dan perlengkapan mandi). 3) Menyimak informasi dari berbagai media seperti radio, televisi, media online, maupun sumber lain yang resmi. Beberapa daftar untuk memperoleh informasi resmi dalam penanganan darurat dari BPBD, BNPB, dan kementerian atau lembaga terkait. Apabila sudah terbentuk posko, informasi lanjutan akan diberikan oleh posko setempat.

Tindakan kesiagaan menghadapi banjir di dalam keluarga : (1) memiliki persediaan pelampung yang cukup untuk anggota keluarga, (2) Pastikan bekal makanan dan persediaan obat-obatan memadai, (3) miliki nomor Ketua RT, RW atau instansi yang dapat dihubungi, (4) Simpan dokumen-dokumen dan surat-surat penting dalam plastik atau kotak tahan air, titipkan salinan dokumen dan surat-surat penting ke kerabat atau orang terpercaya yang tinggal di daerah yang tidak terkena banjir, (5) segera naikkan alat-alat atau kabel-kabel listrik sebelum terkena banjir ke tempat yang lebih tinggi yang tidak terjangkau air banjir, Tutup kran saluran air utama yang mengalir ke dalam rumah, Selalu mendengar informasi tentang perkembangan cuaca.
Tindakan kesiagaan saat terjadi banjir dalam keluarga /perorangan: (1). Mengupayakan jangan panik, tetapi berperilaku tenang dan waspada. 2). Memeriksa apakah diri sendiri atau orang di sekitar terluka, jika perlu beri pertolongan pertama. Ingat untuk menolong orang yang memerlukan bantuan khusus seperti bayi, orang lanjut usia dan orang cacat., 3). Tidak meminum air kecuali setelah dimasak dan tidak menggunakan air tercemar untuk mencuci alat-alat dapur dan pakaian., 4) Tidak membiarkan anak-anak bermain di air banjir., 5) Cermat, mendengarkan informasi darurat dan mengikuti rencana darurat di lingkungan bencana anda., 6). Mengikuti semua instruksi yang disampaikan koordinator posko bencana, serta 7) Melakukan kerjasama yang baik dengan sesame warga lainnya di tempat penampungan.

Tindakan-tindakan oleh keluarga/masyarakat pasca bencana banjir diantaranya: 1). Membersihkan rumah atau tempat tinggal., 2). Menata saluran air dan pori air hujan, 3). Menata tanaman di pekarangan/kebun., 4). Bersama warga lain membantu memperbaiki lingkungan umum dan bantaran sungai, 5). Bersama warga lain,. menanam pohon/ tanaman di lingkungan umum dan membuat pori air di lingkungan jalan, serta 6). Manata alur TPS

Menurut Undang-Undang Nomor 24

Tahun 2007 tentang penanggulangan bencana harus mengaplikasikan prinsip cepat, tepat, praktis, koordinasi dan keterpaduan, berdaya guna dan hasil guna, transparansi dan akuntabilitas, kemitraan, pemberdayaan non diskriminasi dan non proletisi. Ada beberapa stakeholders yang berkaitan erat dengan kesiapsiagaan masyarakat, yaitu: individu dan rumah tangga, instansi pemerintah yang berkaitan dengan pengelolaan bencana, komunitas sekolah, lembaga swadaya masyarakat (LSM) dan organisasi non pemerintah (Ornop), kelembagaan masyarakat, kelompok profesi dan pihak swasta. Dari keseluruhan stakeholders tersebut, tiga stakeholders, yaitu: rumah tangga, pemerintah dan komunitas sekolah, disepakati sebagai stakeholders utama, dan lainnya sebagai stakeholders pendukung dalam kesiapsiagaan bencana. 
Banyak ancaman kesehatan dan jiwa dalam kejadian bencana justru terjadi pada saatsaat kepanikan membubung tinggi dan tak terkendalikan yang seringkali terjadi justru kepanikan yang luar biasa. Saat-saat awal kepanikan dalam suatu kejadian bencana adalah saat-saat yang sangat menenetukan tinggi rendahnya tingkat resiko yang terjadi. Peran keluarga dalam kesiapsiagaan sangat penting, untuk saling mencari informasi bagi keluargannya, mengambil keputusan yang cepat dan sebagai sumber dukungan sosial bagi keluargannya.

Pencegahan dampak bencana harus dimulai dari individu; selama ini pencegahan sekaligus penanganan bencana terlanjur melekat sebagai kewajiban pemerintah sehingga masyarakat tidak siap menghadapi bencana dan pencegahannya. Sosialisasi dan penyuluhan terkait antisipasi bencana harus dilakukan terus menerus agar masyarakat mampu menyiapkan diri terhadap bencana sehingga dapat menurunkan resiko dampak dari bencana tersebut. (Intan et al. 2018).

Strategi pemberdayaan masyarakat dalam penaggulangan antara lain: 1) pemanfaatan nilainilai lokal dan pengetahuan masyarakat setempat yang terkait dengan penaggulangan bencana, 2) pemanfaatan inovasi pengetahuan dan pendidikan untuk membangun budaya keselamatan dan ketahanan pada seluruh tingkatan, 3) pengurangan cakupan resiko bencana alam, 4) mekanisme penaggulangan bencana mencakup: pembentukan resiko bencana alam sebagai prioritas Nasional maupun daerah, peningkatan pemahaman dan pengetahuan masyarakat lokal tentang bencana yang akan terjadi, pembentukan institusi pelaksana yang kuat, terkoordinasi dan efektif, pengadaan dan perbaikan sistem peringatan dini, identifikasi, pengkajian dan pemantauan bencana alam, peningkatan kesiapan menghadapi bencana pada semua tingkatan masyarakat, agar tanggap yang dilakukan lebih efektif, sebaiknya lakukan pula kegiatan simulasi bencana, 5) peningkatan kesadaran masyarakat dalam kesiapsiagaan menghadapi bencana, 6) pemberdayaan peran masyarakat dalam menghadapi bencana yang didapat dari pengalaman (proses belajar dari pengalaman sebelumnya), 7) respon pemerintah daerah dan aparatnya dari instansi sector dalam membangun kesiapsiagaan masyarakat, 8) terlatih, terorganisasi dan terkoordinasinya tenaga lokal (Desa/Kelurahan) dalam penaggulangan bencana alam, 9) dibangunnya kesamaan persepsi tentang kebencanaan dilingkungan masyarakat. (Nurjanah dkk, 2011; Matura, 2011; Purwana, 2013).

Menurut Purwana (2013) masyarakat menyadari bahwa keterlibatan mereka dalam penanggulangan bencana sangat diperlukan, karena secara tidak langsung akan memberikan keuntungan bagi mereka. Disinilah perlunya manajemen yang bisa memberikan arahan dan aturan sehingga bisa mengetahui apa yang seharusnya mereka lakukan untuk kedepannya. Peningkatan kesiapsiagaan masyarakat yang memberikan peningkatan kapasitas masyarakat dapat berupa fisik dan non-fisik. Kegiatan fisik seperti pemanfaatan lahan dengan tepat dan penyediaan tempat evakuasi. Sedangkan peningkatan kapasitas non-fisik seperti mempelajari gejala alam untuk mengetahui tandatanda datangnya bencana, sampai saling mengingatkan di antara sesama untuk siaga dapat membentuk kesiapsiagaan sebagai budaya dalam komunitas masyarakat

Berdasarkan framework kesiapsiagaan terhadap bencana yang dikembangkan oleh LIPI bekerjasama dengan UNESCO atau ISDR, kesiapsiagaan dikelompokan menjadi lima parameter yaitu: 1) Sistem pengetahuan dan sikap (knowledge and attidue), Sistem Pengetahuan dan Sikap (Knowledge and Attidue) merupakan pengetahuan yang dimiliki oleh masyarakat akan mempengaruhi sikap dan kepedulian untuk siap dan siaga dalam mengantisipasi bencana, sehingga masyarakat dapat diberikan pengetahuan dasar tentang bencana alam seperti, ciri, gejala dan penyebabnya 2) Kebijakan dan Panduan, Kebijakan dan panduan merupakan upaya konkret untuk melaksanakan kegiatan siaga bencana yang dapat mempengaruhi kesiapsiagaan meliputi 
pendidikan publik, emergency planning, system peringatan bencana, dan mobilisasi daya termasuk pendanaan, organisasi pengelola, SDM dan fasilitas penting untuk koordinasi darurat bencana. 3) Perencanaan Kedaruratan (Emergency Planning) Perencanaan Kedaruratan (Emergency Planning) dapat dilakukan dengan tindakan apa yang sudah dipersiapkan dalam menghadapi bencana seperti evakuasi, pertolongan dan penyelamatan agar korban bencana dapat diminimalkan. 4) Sistem Peringatan Dini (early warning system) Sistem Peringatan Dini (early warning system) merupakan upaya yang dapat dilakukan oleh masyarakat dalam mencegah korban akibat bencana dengan cara mengenali tanda-tanda peringatan yang ada. Berkaitan hal tersebut, maka diperlukan latihan dan simulasi apa yang harus dilakukan apabila mendengar peringatan, kemana dan bagaimana harus menyelamatkan diri dalam waktu tertentu sesuai dengan lokasi dimana masyarakat sedang berada saat terjadi bencana. 5) Mobilisasi Sumber daya. Mobilisasi Sumber daya lebih kepada potensi dan peningkatan sumber daya di masyarakat melalui keterampilan yang diikuti, dana, prasarana dan sarana lainnya. Hidayati, 2012.

Pendidikan kesiapsiagaan bencana banjir, terutama di wilayah rawan banjir perlu dilakukan secara berulang-ulang dan reguler agar membudaya di masyarakat. Oleh karena itu, agar kesiapsiagaan bencana banjir di masyarakat dapat lebih diperluas lagi, maka perlu dilakukan suatu penyuluhan dan sosialisasi mengenai bencana serta cara siaga dan penanganan bencana banjir sedini mungkin. Pendidikan dan pemahaman tentang kesiapsiagaan adalah serangkaian kegiatan yang harus diketahui untuk mengantisipasi situasi bencana secara cepat dan tepat guna (Djafar et al. 2013)

Peserta kegiatan penyuluhan sangat antusias dan aktif dalam berdiskusi mengenai materimateri yang disampaikan pada penyuluhan ini. Diharapkan ibu-ibu rumah tangga yang juga aktif dalam kegiatan pengajian/yasinan, paham dan menerpapkan perilaku dan tanggap untuk melakukan tindakan-tindakan kewaspadaan berkaitan dengan bencana banjir. Selanjutnya informasi dan implementasi hasil penyuluhan dilaksanakan dari mulai anggota keluarga, agar terbiasa dengan mudah mengimplementasikannya di tataran masyarakat bantaran Sungai Lulut, maupun dengan masyarakat lainnya yang berbatasan dengan wilayah Sungai Lulut ini maupun pada anggota masyarakat di wilayah bantaran sungai lainnya.

\section{KESIMPULAN}

Terdapat peningkatan pengetahuan kesigapan ibu rumah tangga di bantaran Sungai Lulut dalam mitigasi bencana banjir. Diharapkan pengetahuan yang didapat setelah penyeluhan dapat diterapkan oleh mitra sasaran dan dapat diinformasikannya pada masyarakat lainnya di lingkungan rawan banjir

\section{UCAPAN TERIMAKASIH}

Ucapan terimakasih disampaikan kepada Fakultas Kedokteran Universitas Lambung Mangkurat yang telah memberikan bantuan dana hibah PKM tahun anggaran 2021, untuk pelaksanaan kegiatan penyuluhan ini .

\section{REFERENSI}

Anna, Alif N., Suharjo, \& Priyana, Y., (2015), Kajian Biofisik Lahan untuk Penilaian Kerentanan Banjir di DAS Bengawan Solo Hulu, University Research Colloquium 2015 p:9-17.

Aryono, D.P. (2011). The Silent Disaster: Bencana dan Korban Massal, CV. Sagung Seto. Jakarta.

Astuti, S. I. dan Sudaryono, (2010): Peran Sekolah dalam Pembelajaran Mitigasi Bencana" dalam Jurnal Dialog Penanggulangan Bencana, vol. 1(1): 30-42.

Badan Penanggulangan Bencana Daerah 
(BPBD) Kota Banjarmasin, (2021).

"Kondisi Kota Banjarmasin dan Penggunlangan bencama Banjir". Januari 2021

Braun, T., Cottrell, R., \& Dierkes, P. (2018). Fostering changes in attitude, knowledge and behavior: demographic variation in environmental education effects. Environmental Education Research, 24(6),899-920.https:// doi.org/10.1080/13504622.20 17.1343279

Djafar, I, M., Mantu, F, N., \& Patellongi, I, J. (2013). Pengaruh Penyuluhan Tentang Kesiapsiagaan Bencana Banjir Terhadap Pengetahuan dan Sikap kepala Keluarga di Desa Romang Tangaya Kelurahan Tamangapa Kecamatan Manggala Kota Makasar, Jurnal Psikologi Kepribadiandan Sosial.

Hermon , Dedi, (2012), Mitigasi Bencana Hidrometeorologi, Padang: UNP Press

Hidayati, D. (2012). Akses dan Keterlibatan Perempuan dan Laki-laki Dalam Penanganan Bencana dalam Pengelolaan Bencana Berbasis Gender: Pembelajaran Dari Gempa Bantul 2006. Editor Deny Hidayati. Jakarta: PT Dian Rakyat dan PPK-LIPI

Intan, A.P., dkk. (2018). Indonesian Cities Green Development Index: A Prototype Measurement, International Journal of Sciences: Basic and Applied Research, 31 (3): 290-308.

Konsorsium Pendidikan Bencana Indonesia. (2011). Kerangka Kerja Sekolah Siaga Bencana. Jakarta. http://gerashiaga.files.wordpress.com/2012/ 06/bukukerangka-kerjasekolah-siagabencana.pdf.

Matura (2011). Pedoman Nasional Manajemen Bencana di Indonesia. Gama Media.
Yogyakarta

Mustofa, B., dan Inung, S. (2010). Kamus Lengkap Geografi. Yogyakarta: Panji Pustaka.

Nefilinda, Slamet Rianto \& Jamsari. (2019). Sosialisasi Pemahaman Kebencanaan di Kelurahan Pasie Nan Tigo, Kecamatan Koto Tangah, Kota Padang. Seminar Nasional Pemberdayaan Masyarakat, Pekanbaru, 2019- 08-21. ISSN 2685-9017. conference.unri.ac.id

Nefilinda, Slamet Rianto \& Jamsari. (2019). Pengabdian Mitigasi Bencana di Kelurahan Pasie Nan Tigo Kecamatan Koto Tangah Kota Padang. Jurnal Rangkiang. UP3M STKIP PGRI Sumatera Barat. ISSN: (27212688) Vol. 1, No 2. (Desember2019):7869.https://doi.org/10.22202/JR.2020.V1i2.3 853

Nugroho, S.P., (2015), Relevansi Meningkatnya Bencana Hidrometeorologi terkait Kerusakan DAS di Indonesia, Prosiding Seminar Nasional Restorasi DAS: Mencari Keterpaduan di Tengah Isu Perubahan Iklim, Surakarta: BPTKPDAS.

Nurjanah, R., Sugiharto, Dede, K., Siswanto B.P., Adikoesoemo. (2011). Manajemen Bencana, Bandung, Alfabeta.

Ryan Sakti Seto Kumoro. 2013. Kesiapsiagaan masyarakat dalam menghadapi bencana banjir di desa langenharjo kecamatan grogol kabupaten sukoharjo (Skripsi).Surakarta: Universitas Muhammadiyah Surakarta

Undang-Undang No. 24 Tahun 2007 tentang Penanggulangan Bencana. (2007).

Purwana. R., (2013). Manajemen Kedaruratan Kesehatan Lingkungan dalam Kejadian Bencana, PT. Raja Grafindo Persada. Jakarta 
Puturuhu, F., (2015), Mitigasi Bencana dan Pengeinderaan Jauh, Cetakan ke 1, Yogyakarta: Graha Ilmu.

Vidergor, H. E. (2018). Effectiveness of the multidimensional curriculum model in developing higher-order thinking skills in elementary and secondary students. The Curriculum Journal, $\quad$ 29(1), 95-115. https://doi.org/10.1080/09585176.20 $\underline{17.1318771}$

Watson, L., Hegtvedt, K., Johnson, C., Parris,C., Subramanyam,S. (2017). When legitimacy shapes environmentally responsible behaviors: Considering exposure to university sustainability initiatives. Education $\quad$ Sciences, $\quad 7(1), 13$. https://doi.org/10.3390/educsci7010 013

Widayatun dan Zainal Fatoni, (2013) Permasalahan Kesehatan Dalam Kondisi Bencana: Peran Petugas Kesehatan dan Partisipasi Masyarakat. urnal Kependudukan Indonesia Vol. 8 No.1 Tahun 2013 (ISSN 1907-2902). 37-46. 